\title{
THE INTERNET - A RISK-TAKING SPACE FOR UNIVERSITY STUDENTS
}

\author{
KAMILA WYLĘGEY \\ University of Wrocław, Institute of Pedagogy \\ ul. Dawida 1, 50-527 Wrocław \\ E-mail address: wylegly.kamila@gmail.com \\ ORCID: https://orcid.org/0000-0001-9787-5046
}

\begin{abstract}
Aim. The purpose of this article is to analyse risky behaviours undertaken by university students on the Internet.

Theory. The concepts of "risk" and "risky behaviour" are known and often discussed in science. Krzysztof Ostaszewski (2005) defines risky behaviours as actions that contradict social norms and legal order, which at the same time pose a threat to a person's health and development. The catalogue of risky behaviours is very diverse andmore importantly-open. With the development of civilisation, new forms appear. Examples include risky behaviours on the Internet.

Methodology and research results. The study population sample consisted of 241 university students. The research was conducted using an online survey questionnaire. The respondents admitted to taking risks in the virtual world. A large percentage of respondents admit to sharing private information on social networks (almost 70\%). Nearly 75\% of respondents ignore communications about potential threats to websites, putting themselves at risk of losing sensitive data. Moreover, $65.1 \%$ of students admit to downloading content from illegal sources. Other risky behaviours undertaken by students on the Internet include Internet addiction and online activities, aggression on the Internet, sexual and/or erotic behaviour in cyberspace. The paper also presents the answers to open-ended questions, which refer to threats on the Internet as perceived by the students. The answers given most often referred to: addiction to new technologies, loss/theft of private data, vulnerability to false/ unverified information available on the Internet.

Cognitive value. Online risk-taking is a global problem. The phenomenon should be further theoretically considered and analysed in a pedagogical practice.

Key words: Zuckerman's sensation-seeking theory, problem behavior theory, cyberbullying, online risk, university students
\end{abstract}

\section{INTRODUCTION}

The Internet is a very specific medium that combines elements of culture, multimedia, and hyper-communication. It results in the creation of a new environment and a new culture. Cyberspace promotes the development of

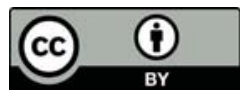


new social relations and new ways of understanding the world. Therefore, it is of interest to specialists in pedagogy, sociology, and psychology. However, the Internet is also associated with the appearance of new threats. Most of them have already been described in detail in the literature. Children and young people are particularly exposed to risks on the Internet. Nevertheless, these dangers may also affect adults, including university students (Gałkowski, 2003; Wojtkowiak \& Szumilas-Praszek, 2013).

On the scientific ground, such problems among students have been analysed as: spending too much time online and addiction to new technologies (Dembińska \& Ochnik, 2014; Warzecha, 2014, 2015; Garwol, 2016; Olawade, Olorunfemi, Wada, Afolalu, \& Enahoro, 2020; Zenebe, Kunno, Mekonnen et al., 2021), online aggression (Brewer, Cave, Massey, Vurdelja, \& Freeman, 2012; Xiao \& Wrong, 2013; Johnson, Haralson, Batts et al. 2016), internet gambling (McBride \& Derevensky, 2012), online sexual behaviour (Döring, Daneback, Shaughnessy, Grov, \& Byers, 2017) and the impact of media communications on the perception of the world (Tkáčová, Pavlíková, Tvrdoň, \& Jenisová, 2021).

The research conducted for this paper served to analyse the phenomenon among Polish university students. They made it possible to compare the data with the results conducted by the mentioned authors in previous years and to diagnose other forms of risky behaviours among students.

\section{RISKS AND RISKY BEHAVIOUR}

The term "risk" comes from the Latin word "risicare." Etymologically it means "to avoid something." The term (often used) by Roman sailors meant the danger of swimming around rocks and cliffs (Kwiatkowska, 2012). To the scientific dictionary, the risk term was introduced by geographers and sociologists. Later, the word began to be used by psychologists and representatives of other disciplines (Kwiatkowska, 2012). In the Cambridge Dictionary Online we can find explanations: "the possibility of something bad happening" and "something bad that might happen" (Cambridge Dictionary, n.d).

The definitions quoted show that "risk" is inextricably connected with uncertainty and the potential negative consequences of actions taken. Tadeusz T. Kaczmarek (2005) claims that risk differs from danger because the second means some direct threat. We speak of risk only when we are not sure of its consequences. A risk is not a certain loss.

In the literature, a distinction is drawn between "instrumental risk" and "stimulus risk." Instrumental risk is obligatory in nature and can be explained by "risk-sensitivity theory" (RST). This theory was formulated for behavioural ecology to explain the propensity for risk motivated by necessity (Kacelnik \& Bateson, 1996; Shafir, 2000; Krebs \& Davies, 2001; Zaleśkiewicz, 2006). The theory is mainly applied in the interpretation of animal behaviour that chooses between safe and risky ways of foraging and acquiring food. The concept assumes that the animal chooses the precautionary form as long as the 
expected amount of food exceeds the norm necessary for survival. However, it appears that RST is also applicable to humans. Catrin Rode, Leda Cosmides, Wolfgang Hell, \& John Tooby (1999) have shown that humans (like animals) prefer risk when that action is necessary to achieve a set or imposed aspiration. Tomasz Zaleśkiewicz (2006) defines such action as an instrumental risk because it does not represent any value - it is only a tool to achieve a positive (or avoid a negative) result.

Stimulus risk can be explained by "Zuckerman's sensation-seeking theory" (1994), in which the author emphasises that people seek new and intense sensations, even if they involve taking risks: physical, social, financial, or legal. According to Marvin Zuckerman (1994), these activities are not goal-oriented, but rather the course and the arousal that accompanies them.

The concept of "risk," like that of "risky behaviour," has received a lot of scientific attention. Richard and Shirley Jessor (1997) should be considered the forerunners of the concept of risky behaviour. They defined this phenomenon and drew attention to its negative health or developmental consequences (Jessor, 1991, 1998). Krzysztof Ostaszewski (2005) explains risky behaviours as activities that are anti-normative and remain in opposition to the social and legal order. At the same time, they are a threat to the health and development of an individual. Joanna Szymańska (2012) emphasises the importance of pejorative consequences for the psycho-physical health of the person, but also for the entire surrounding environment. Charles E. Irwin Jr. (1990) writes about risky behaviours that they are actions undertaken under compulsion or of one's own free will. Their consequences are unpredictable with one exception - they have a negative impact on one's health.

Danice K. Eaton, Laura Kann, Steve Kinchen et al. (2006) report a range of risk behaviours, including: tobacco use, all sexual behaviours which contribute to an unplanned pregnancy and sexually transmitted diseases, disordered diets, use of alcohol and other psychoactive substances, physical inactivity, and others. The catalogue of risk behaviours is long and varied. Alan E. Kazdin (1996, in: Szymańska, 2014) includes among the most popular: alcohol drinking, smoking, early sexual initiation, criminal and aggressive behaviour, etc. Importantly, this catalogue is not closed. It results from the development of civilisation (Klonowska, 2016) - new forms of risk constantly appear. Mariusz Z. Jędrzejko, Sławomir Kania, \& Paweł Prüfer (2017) describe new risk behaviours consequent upon contemporary culture and socially promoted patterns, e.g. smoking e-cigarettes, sugar abuse, OTC (over-the-counter) drug abuse, body modification, bigorexia, sleep shortening, information overload, etc.

\section{RISK ON THE INTERNET}

It is worth mentioning another developing problem (undoubtedly intensified by the COVID-19 virus pandemic), which is undertaking "risky behaviour online". Jacek Pyżalski (2013) writes that these are online activities undertaken 
by young people. They pose a threat to themselves and others. Moreover, according to Pyżalski (2013), the online risk is related to a young person's own direct activity - this action (or failure to act) increases the likelihood of victimisation.

Online risky behaviours can take many forms:

- giving out personal details to strangers you meet on the Internet (Livingstone \& Helsper, 2007, 2010; Ybarra, Mitchell, Finkelhor, \& Wolak, 2007);

- making one's data and/or photos available on the Internet, setting them in "public status," visible to all Internet users (Marcum, Ricketts, \& Higgins, 2010; Ybarra, et al., 2007);

- engaging in online discussions about sex with strangers (Ybarra et al., 2007);

- online friendships with strangers (Livingstone \& Helsper, 2007; Ybarra et al., 2007);

- adding strangers to online contact/friendship lists (Livingstone \& Helsper, 2010; Ybarra et al., 2007);

- meeting online acquaintances in the real world (Livingstone \& Helsper, 2007; Ybarra et al., 2007);

- concealing one's identity on the Internet, impersonating someone else (Livingstone \& Helsper, 2010);

- posting vulgar/offensive comments on the Internet, insulting, harassing (Ybarra et al., 2007).

Andrzej Adamski (2003) observes that the global character, anonymity, and universality of access to the Internet make it not only a space that may encourage risky behaviours, but also a good environment for the development of crime. A user who is not aware of the fact that the Internet may be used as a tool to violate socio-legal norms is exposed to many threats.

Many typologies of Internet dangers have been described in the literature. An example is a classification by Piotr Sienkiewicz and Halina Świeboda (2006), who point to: illegal and offensive content, information gathering (e.g. through eavesdropping), attempts to break into software systems, intrusions into private user accounts, malicious software/ malware, unauthorised access to information, fraud on the Internet, restricted access to Internet resources (e.g. blocking of servers). Agnieszka Szewczyk (2008) also describes: hacking into private accounts, fraud and extortion, voyeurism, pedophile contacts, the risk of children viewing harmful content (e.g. pornography), spreading harmful ideologies, breaking and infringing copyrights, contact with the members of criminal organisations, finding instructions on how to use weapons, drugs, and other harmful objects or substances.

A widespread phenomenon receiving increasing attention is "cyberbullying." Nancy Willard (in: Pyżalski, 2012) defines this concept as sending cruel or offensive images and content via the Internet and other communication tools. Robert Slonje and Peter Smith (2008) draw attention to acts of aggression carried out through modern technologies, primarily the Internet and mobile phones. Furthermore, Jaana Juvonen and Elisheva Gross (2008) argue 
that cyberbullying is based on insulting and threatening others using digital technologies.

While discussing the dangers of Internet use, behavioural addictions cannot be ignored. A pioneer of research on Internet addiction, Mark Griffiths $(1996,2000)$, coined the term "technological addiction," which is understood as a behavioural (non-chemical) intimacy/interaction between a person and a device. This author distinguished the following elements which constitute the phenomenon:

- salience - an activity becomes the most important for a person. It is the dominant area of the activity;

- mood modification - changes in mood which may be manifested as calmness, a sense of escape, stupor, or overexcitement. These changes result from engagement in a particular activity;

- tolerance - a process that involves increasing the range of activities necessary to achieve a state of euphoria - like the first time of doing an activity. People need to do an activity longer than before to achieve the same level of satisfaction and enjoyment;

- Withdrawal - withdrawal symptoms appear when an activity is discontinued or abruptly reduced. It also includes unpleasant physical symptoms;

- conflict - all interpersonal and intrapsychic conflicts caused by the activity;

- relapse - a tendency to return to pathological patterns of the activity. An individual manifesting symptoms of addiction is able to return to extreme stages of an activity despite previous abstinence.

In literature and social campaigns, a lot of attention has been given to children as victims of risky behaviours on the Internet. Nevertheless, it is worth emphasising that adults may also experience various forms of cyberbullying. What is more, they are more likely to initiate it themselves. Therefore, it is worth analysing other age groups, including university students.

\section{METHODOLOGY}

Based on the definitions of "risk," "risky behaviour," and "online risky behaviour," the aims of the discussion were as follows: 1) the analysis of online behaviours which are incompatible with social norms or/and the legal order; 2) the analysis of online behaviour that poses a threat to the health/development of a student; 3) the analysis of behaviour that poses a threat to other Internet users.

The behaviour discussed is framed by several theoretical strands:

- an addiction to the Internet and online activities (online gambling, online shopping, online games) - symptoms of behavioural addictions related to new technologies,

- online aggression (badmouthing, cyberbullying, vulgarity),

- sexual and/or erotic behaviour on the Internet,

- online sharing of personal data, social exposure on the Internet,

- use of illegal and/or unverified sources. 
The survey included 241 students from Polish higher education institutions. The purposeful selection was used in the study. Questionnaires in the online survey were made available on social networking sites, in student community groups. The form used resulted from the COVID-19 epidemic situation, in which direct contact with the respondents would have been impossible. Moreover, the topic of the survey could be considered controversial and/or embarrassing. Therefore, it was assumed that the online survey could reduce the feeling of discomfort for the respondents (Batorski \& Olcon-Kubicka, 2006), and thus - positively influence the reliability of the results obtained.

The survey questionnaire consisted of 40 questions: 32 of them fulfilled the criteria of the attitude scale. Two questions were open-ended - the respondent gave a written answer about the dangers of using the Internet in his/her opinion.

The results obtained are presented in a percentage form. The inclusion of qualitative content analysis (from the open-ended questions) is intended to characterise the phenomenon more accurately and to view the problem from the student's perspective. This approach made it possible to gain data that could not have been obtained using the attitudes scale alone.

\section{TEST RESULTS}

Table 1.

Symptoms of behavioural addictions involving new technologies

\begin{tabular}{|c|c|c|c|c|c|}
\hline \multirow[t]{2}{*}{ Phenomenon/problem } & \multicolumn{5}{|c|}{ Frequency (\%) } \\
\hline & always & often & sometimes & rarely & never \\
\hline $\begin{array}{l}\text { A sense of fear and irritation } \\
\text { when there is no Internet } \\
\text { access }\end{array}$ & 2.1 & 9.5 & 27 & 35.7 & 25.7 \\
\hline $\begin{array}{l}\text { Spending more than } 4 \text { hours a } \\
\text { day on the Internet (except for } \\
\text { education and work) }\end{array}$ & 21.6 & 32.4 & 28.6 & 14.1 & 3.3 \\
\hline $\begin{array}{l}\text { A strong, unjustified need to } \\
\text { make Internet shopping }\end{array}$ & 1.2 & 9.5 & 13.7 & 32.8 & 42.7 \\
\hline $\begin{array}{l}\text { Playing online games for } \\
\text { several hours during the day }\end{array}$ & 4.6 & 6.6 & 13.3 & 29.9 & 45.6 \\
\hline Gambling online & 0 & 0.4 & 0.4 & 1.2 & 97.9 \\
\hline
\end{tabular}

Note: $\mathrm{n}=241$

Source: own research.

Table 1 shows that students spend a lot of their free time on Internet activities. $32.4 \%$ of the respondents admitted that they often spend more than $4 \mathrm{~h}$ (outside of work and distance education) surfing the Internet, while more than $96 \%$ of the students do it all the time, often, rarely, or sometimes. Approximately $75 \%$ of the respondents feel a sense of dread and irritability when they do not have access to the Internet. The fact that more than half of the respond- 
ents have (or regularly feel) a strong, unreasonable urge to shop online should be considered worrying. Only a few people admitted to gambling online.

Table 2.

Frequency of behaviour intended to offend/humiliate another person on the Internet or to expose him/her to material damage

\begin{tabular}{lccccc}
\hline \multicolumn{1}{c}{ Phenomenon/ problem } & \multicolumn{5}{c}{ Frequency (\%) } \\
\cline { 2 - 6 } & always & often & sometimes & rarely & never \\
$\begin{array}{l}\text { Offending other people or } \\
\text { social groups on the Internet }\end{array}$ & 0.4 & 0.4 & 3.3 & 6.6 & $\mathbf{8 9 . 2}$ \\
$\begin{array}{l}\text { Posting comments with vulgar } \\
\text { content on the Internet }\end{array}$ & 0.4 & 1.2 & 0.8 & 5 & $\mathbf{9 2 . 5}$ \\
$\begin{array}{l}\text { Impersonating others on the } \\
\begin{array}{l}\text { Internet in order to inflict } \\
\text { personal or material damage } \\
\text { on them }\end{array}\end{array}$ & 0 & 0 & 0 & 0 & $\mathbf{1 0 0}$ \\
$\begin{array}{l}\text { Humiliation/ ridicule other } \\
\text { people in the online discussion } \\
\text { forum }\end{array}$ & 0 & 1.7 & 1.7 & 3.3 & $\mathbf{9 3 . 4}$ \\
\hline $\begin{array}{l}\text { Note: } \mathrm{n}=241 \\
\text { Source: } \text { own research. }\end{array}$ & & & & & \\
\hline
\end{tabular}

Table 2 shows behaviour causing personal or property harm to others on the Internet. The results confirm that such actions are rarely undertaken by students. Over $92 \%$ of the respondents do not insult other persons (including public figures) or social groups on the Internet. Only $7.5 \%$ of the respondents post vulgar comments on the Internet, and about $6.5 \%$ of the students admit to humiliating other persons in an Internet discussion forum.

Table 3.

Frequency of sexual behaviour on the Internet

\begin{tabular}{lccccc}
\hline \multicolumn{1}{c}{ Phenomenon/ problem } & \multicolumn{5}{c}{ Frequency (\%) } \\
\cline { 2 - 6 } & always & often & sometimes & rarely & never \\
$\begin{array}{l}\text { Posting negligee/ erotic photos } \\
\text { on the Internet }\end{array}$ & 0 & 2.1 & 2.9 & 12.4 & $\mathbf{8 2 . 6}$ \\
$\begin{array}{l}\text { Sending out sexual messages to } \\
\text { strangers }\end{array}$ & 0 & 1.7 & 2.1 & 3.7 & $\mathbf{9 2 . 5}$ \\
$\begin{array}{l}\text { Sending erotic photos to other } \\
\text { people over the Internet }\end{array}$ & 1.2 & 4.6 & 7.9 & 11.2 & $\mathbf{7 5 . 1}$ \\
$\begin{array}{l}\text { Note: } \mathrm{n}=241 \\
\text { Source: } \text { own research. }\end{array}$ & & & & & \\
\end{tabular}

The study also took into account erotic-oriented online behaviours, which may pose a threat to respondents and other Internet users. The table shows that more than $17 \%$ of participants post pictures of themselves in underwear and/or photos of erotic character on the Internet. Moreover, almost 25\% send 
erotic photos to other people on the web. This is a major threat because private pictures can get to "third persons" and be used against the sender. Only 18 people $(7.5 \%)$ admitted to sending sexual messages to strangers

Table 4.

Frequency of sharing your private personal data or facts of your private life on the Internet

\begin{tabular}{|c|c|c|c|c|c|}
\hline \multirow[t]{2}{*}{ Phenomenon/problem } & \multicolumn{5}{|c|}{ Frequency $(\%)$} \\
\hline & always & often & sometimes & rarely & never \\
\hline $\begin{array}{l}\text { Posting photos on social } \\
\text { networking sites without } \\
\text { privacy settings }\end{array}$ & 3.7 & 12.4 & 12 & 37.3 & 34.4 \\
\hline $\begin{array}{l}\text { Posting detailed information } \\
\text { and facts from private life on } \\
\text { the Internet }\end{array}$ & 0 & 2.1 & 6.2 & 32.4 & 59.3 \\
\hline $\begin{array}{l}\text { Sharing personal data with } \\
\text { others on social networking } \\
\text { sites }\end{array}$ & 1.7 & 10.4 & 26.1 & 30.7 & 31.1 \\
\hline
\end{tabular}

In Table 4, it can be observed that many students are not concerned about their privacy. Almost 70\% of the respondents admitted that they regularly, frequently, or occasionally share their personal information on social networking sites. More than $40 \%$ of students post facts and information from their private life on the Internet (the highest number of people admitted that they do so rarely $-30.7 \%$ which constitutes 74 people). Only $34.4 \%$ (83 people) admitted that they never post photos of themselves online without setting privacy settings ("public photos").

Table 5.

Frequency of use of illegal/dangerous websites

\begin{tabular}{lccccc}
\hline \multicolumn{1}{c}{ Phenomenon/ problem } & \multicolumn{5}{c}{ Frequency (\%) } \\
\cline { 2 - 6 } & always & often & sometimes & rarely & never \\
$\begin{array}{l}\text { Downloading content from } \\
\text { illegal sources }\end{array}$ & 2.1 & 10 & 24.1 & 29 & 34.9 \\
$\begin{array}{l}\text { Online shopping for products } \\
\text { prohibited by law }\end{array}$ & 0 & 0.8 & 0 & 0.8 & 98.3 \\
$\begin{array}{l}\text { Use of websites despite } \\
\text { communications about } \\
\text { potential security threats }\end{array}$ & 2.1 & 8.7 & 26.1 & 37.3 & 25.7 \\
$\begin{array}{l}\text { Note: } \mathrm{n}=241 \\
\text { Source: } \text { own research. }\end{array}$ & & & & & \\
\hline
\end{tabular}

A significant number of the respondents $(65.1 \%, \mathrm{n}=157)$ admit to downloading content from illegal sources on a regular, frequent, or occasional basis. 
In the survey, students were also asked about the sources from which they obtain literature for e-learning. More than $90 \%$ of respondents admitted that they gain materials from illegal sources (always, often, or occasionally). Moreover, approximately $75 \%$ are careless about their data, accessing sites despite danger warnings. However, more than $98 \%$ of students claim that they have never bought products prohibited by law over the Internet-only 4 persons admitted that they do so often or rarely.

Besides the data on percentages, it is worth quoting the students' statements on the risks resulting from the use of the Internet. The answers most often referred to addiction to new technologies, loss/theft of private data, sharing one's personal data and private material with inappropriate people, inability to establish relationships in the real world as a result of excessive isolation, as well as vulnerability to false/unverified information on the Internet.

Selected student statements are presented below:

- "Lack of privacy, addictions, being closed in 'an information bubble,' health problems (lack of physical activity), decreased self-esteem" (W, 21 ${ }^{1}$ );

- "Data leakage, phishing, sending photos to inappropriate people" (W, 21);

- "Weakening of bonds and inability to communicate with another person face to face" (W, 21);

- "Problems with concentration, procrastination" (M, 21);

- "Risk of addiction-especially among younger children who are most vulnerable to its negative effects. The Internet is also a place where you can anonymously humiliate and insult others. In addition, during remote examinations there is a high risk of 'cheating' and this reduces the value of education" (W, 22);

- "Bullying, pornography, data theft" (W, 22);

- "Someone may gain our sensitive personal data or we may share it ourselves without knowing the consequences; lots of viruses on various dangerous sites" (W, 22);

- "Excessive anonymity increases the risk of the behaviour of an illegal nature, e.g. exploitation of minors" (W,22).

It can be observed that each of the mentioned statements suggests many different risks. Importantly, students spend many hours on activities related to new technologies despite being well aware of their consequences.

\section{SUMMARY AND CONCLUSIONS}

The COVID-19 pandemic has obliged people to carry out many activities on the Internet. Online work and education have become an everyday reality. This in turn may intensify addictions to new technologies and result in many health problems. Every additional hour spent in front of a monitor or smartphone screen can pose a threat to mental and physical health. Therefore,

1 Note: (W - woman/ M - man, age) 
it is alarming that over $96 \%$ of those surveyed admit to spending more than 4 hours a day on online activities unrelated to their compulsory education and work duties. Also worrying are the symptoms of online behavioural addictions, such as shopping, gambling, and online games.

Research has shown that many students do not care about their personal data on the Internet. A large percentage of respondents admit to sharing private information on social networking sites. Moreover, almost $75 \%$ of respondents ignore information about potential threats on websites, exposing themselves to the risk of losing sensitive data. At this point, it is also worth mentioning the photos shared. Many users post pictures in cyberspace with the status "public," which are available to all Internet users. In addition, more than $17 \%$ of respondents post pictures in underwear/swimsuits/negligee on the Internet. This is not only a form of crossing the boundaries of intimacy on the Internet but also a form of danger - such photos may be found by people who will use them for purposes harmful to the authors (including health risks). A similar danger arises from sending erotic photos over the Internet. It may seem that sharing such pictures only with the closest persons (e.g. partners) does not carry any risks. However, there is the possibility of data leaks into cyberspace, which can also have negative consequences.

It is worrying that many students are downloading content from illegal sources-both literature for distance learning courses and other material. Admittedly, there is a limited access to library collections during the pandemic. However, universities provide literature in electronic form. The same applies to access to all forms of culture-for a small fee (sometimes even for free) it is possible to use legal services.

Fortunately, only a small percentage of students admitted to insulting and/ or humiliating other people or social groups on the Internet. All respondents denied being asked about impersonating other people in order to cause them material or personal harm.

It is commonly accepted that the generation of people born after 1980 are "digital natives" 2 because they excel in the world of new technologies. They consciously use the media to achieve their goals and satisfy their needs on various levels. These people grew up in a world full of technology, so they consider new media a natural part of the surrounding reality (Prenksy, 2001; Tapscott, 2010; Morbitzer, 2011-2012; Skibińska, 2015).

Nevertheless, everyday "functioning" in virtual space requires knowledge of the dangers "lurking" in it. Young people should be educated about the safe use of the Internet, as well as the legal and social consequences of violating norms in the cyber world. This education should be the responsibility of educationalists, psychologists, and especially parents.

2 A discussion on this topic is undertaken by Marc Prensky. He was the first to use the term "digital natives." For more information, see: http:/ / marcprensky.com/. 


\section{REFERENCES}

[1] Adamski, A. (2003). Karnoprawna ochrona dziecka w sieci Internet [Criminal law protection of children on the Internet], Prokuratura i Prawo, 9, 59-75.

[2] Batorski, D., \& Olcoń-Kubicka, M. (2006). Prowadzenie badań przez Internet - Podstawowe zagadnienia metodologiczne [Conducting Research Online - Principal Methodological Issues, Studia Socjologiczne, 3(182), 100-130.

[3] Brewer, B., Cave, E., Massey, A., Vurdelja, A., \& Freeman, J. (2012). Cyber Bullying Among Female College Students: An Exploratory Study, Californian Journal of Health Promotion, 12(1), 40-51.

[4] Cambridge Dictionary. (n.d.). Risk. Retrieved 3 April, 2021, from: https:// dictionary.cambridge. org/pl/dictionary/english/risk

[5] Dembińska, A., \& Ochnik, D. (2014). Use of Internet and its addictive risk among Polish students - comparative analysis over a seven-year period, Polish Journal of Applied Psychology, 12(4), 53-68.

[6] Döring, N., Daneback, K., Shaughnessy, K., Grov, C., \& Byers, E. S. (2015). Online Sexual Activity Experiences among College Students: A Four-Country Comparison, Archives of Sexual Behavior 46(6), 1641-1652. DOI:10.1007/s10508-015-0656-4.

[7] Eaton, E. K., Kann, L., Kinchen, S., Ross, J., Hawkins, J., Harris, W. A., Lowry, R., McManus, T., Chyen, D., Shanklin, S., Lim, C., Grunbaum, J. A., \& Wechsler, H. (2006). Youth Risk Behavior Surveillance - United States, 2005, Surveillance Summaries, June 9/ 55(SS05), 1-108. Retrieved 8 April, 2021, from:

[8] https://www.cdc.gov/mmwr/preview/mmwrhtml/ss5505a1.htm

[9] Gałkowski, J. P. (2003). Internet dzieli klasy i osoby [The Internet divides classes and people], Edukacja i Dialog, 6, 12-17.

[10] Garwol, K. (2016). Studenci w sieci - sposoby, rodzaje i motywacje przebywania w cyfrowym świecie na przykładzie studentów Uniwersytetu Rzeszowskiego, Studia Informatica Pomerania, 2(40), 27-37.

[11] Griffiths, M. (1996). Internet addiction: An issue for clinical psychology? Clinical Psychology Forum, 97, 32-36.

[12] Griffiths, M. (2000). Does Inernet and computer "addiction" exist? Some case evidence, Cyberpsychology and Behavior, 3, 211-218.

[13] Irwin, C. E., Jr. (1990). The theoretical concept of at-risk adolescents, Adolescent Medicine: State of the Art Reviews, 1, 1-14.

[14] Jessor, R. (1991). Risk behavior in adolescence: A psychosocial framework for understanding and action, Journal of Adolescent Health, 12, 597-605.

[15] Jessor, R., \& Jessor, S. (1997). Problem behavior and psychological development: a longitudinal study of youth. Nowy Jork: Academic Press

[16] Jessor, R. (1998). New perspectives on adolescent risk behavior. Cambrige Uiversity: New York Press.

[17] Jędrzejko, M., Prüfer, P., \& Kania, S. (2017). Wprowadzenie. Zachowania ryzykowne - kluczowe tendencje i ich następstwa. In: A. Dobrychłop, M. Jędrzejko, S. Kania, K. Kasprzak, J. Matejek, P. Prüfer, D. Szarzała, R. B. Sieroń, A. Szwedzik, \& A. Taper (Eds.), Zachowania ryzykowne nastolatków. Nowa jakość ryzyka - Ryzyka wielowymiarowe. Ujęcie socjopedagogiczne [Teenagers' risky behaviors. The new quality of risk - Multidimensional risks. A socio-pedagogical approach] (pp. 57-81). Warszawa-Milanówek: ASPRA-JR.

[18] Johnson, L. D., Haralson, A., Batts, S., Brown, E., Collins, C., Van Buren-Travis, A., \& Spencer, M. (2016). Cyberbullying on Social Media Among College Students. Article 3, Ideas and Research You Can Use: VISTAS, 1-8.

[19] Juvonen, J., \& Gross, E. F. (2008). Extending the school grounds? - Bullying experience in cyberspace, Journal of School Health, 78, 496-505. DOI: https://doi. org/10.1111/j.1746-1561.2008.00335.x

[20] Kacelnik, A., \& Bateson, M. (1996). Risky Theories - The Effects of Variance on Foraiging Decisions, American Zoologist, 36, 402-434.

[21] Kaczmarek, T. T. (2005). Ryzyko i zarządzanie ryzykiem. Ujęcie interdyscyplinarne [Risks and Risk Management. Interdisciplinary Approach]. Warszawa: Diffin. 
[22] Kazdin A. (1996). Zdrowie psychiczne młodzieży w okresie dorastania. Programy profilaktyczne i lecznicze [The mental health of youth in adolescence. Prevention and treatment programs], Nowiny Psychologiczne, 2, 39-74

[23] Klonowska, I. (2016). Psychopedagogiczne i kryminologiczne aspekty zachowań ryzykownych młodzieży [Psychopedagogical and criminological aspects of risky behavior of adolescents], Resocjalizacja polska, 11, 84-85

[24] Krebs, J. R., \& Davies, N. B. (2001). Wprowadzenie do ekologii behawioralnej [An introduction to behavioural ecology]. Warszawa: PWN.

[25] Kwiatkowska, G. E. (2012). Jednostka w społeczeństwa ryzyka. In: G. E. Kwiatkowska, \& I. Siudem (Eds.), Zachowania ryzykowne. Analiza wspótczesnych zjawisk spotecznych [Risky behaviours. Analysis of contemporary social phenomenon] (pp. 9-32). Lublin: Wydawnictwo Uniwersytetu Marii Curie-Skłodowskiej.

[26] McBride, J., \& Derevensky, J. (2012). Internet gambling and risk-taking among students: An exploratory study, Journal of Behavioral Addictions 1(2), 50-58. DOI: 10.1556/JBA.1.2012.2.2

[27] Morbitzer, J. (2011-2012). O istocie medialności młodego pokolenia [About the nature of the young generation mediality], Neodidagmata, 33/34, 131-153.

[28] Livingstone, S., \& Helsper, E. J. (2007). Taking risks when communicating on the internet: The role of offline social-psychological factors in young people's vulnerability to online risks, Information, Communication and Society, 10(5), 619-643. DOI: 10.1080/13691180701657998.

[29] Livingstone, S., \& Helsper, E. J. (2010). Balancing opportunities and risks in teenagers' use of the internet: The role of online skills and internet self-efficacy, New Media \& Society, 12(2), 309-329. DOI: 10.1177/1461444809342697.

[30] Olawade, D. B, Olorunfemi, O. J., Wada, O. Z., Afolalu, T. D., \& Enahoro, M. A. (2020). Internet Addiction among University Students during Covid-19 Lockdown: Case Study of Institutions in Nigeria, Journal of Education and Human Development, 9(4), 165-173. DOI: 10.15640/ jehd.v9n4a17

[31] Ostaszewski, K. (2005). Podstawy teoretyczne profilaktyki zachowań problemowych. In: M. Deptuła (Ed.), Diagnostyka, profilaktyka, socjoterapia w teorii i praktyce pedagogicznej [Diagnostics, prevention, sociotherapy in pedagogical theory and practice] (pp. 111-137). Bydgoszcz: Wydawnictwo Uniwersytetu Kazimierza Wielkiego.

[32] Prenksy, M. (2001). Digital Natives, Digital Immigrants (From On the Horizon, Vol. 9 No. 5, MCB University Press, October 2001). Retrieved 29 March, 2020, from https:/ /www.marcprensky.com/writing/Prensky\%20-\%20Digital\%20Natives, \%20Digital\%20Immigrants\%20 -\%20Part1.pdf

[33] Pyżalski, J. (2012). Agresja elektroniczna i cyberbullying jako nowe ryzykowne zachowania młodzieży [Electronic aggression and cyberbullying as new risky behaviors of teenagers]. Kraków: Impuls.

[34] Pyżalski, J. (2013). Rodzina i szkoła a przeciwdziałanie zaangażowaniu młodych ludzi w ryzykowne zachowania online [Family and school and preventing young people from engaging in risky online behaviors], Dziecko Krzywdzone. Teoria, badania, praktyka, 12(1), 99-109.

[35] Rode, C., Cosmides, L., Hell, W., \& Tooby, J. (1999). When and why do people avoid unknown probabilities in decisions under uncertainty? Testing some predictions from optimal foraging theory, Cognition, 72, 269-304.

[36] Shafir, S. (2000). Risk-sensitive foraging: the effect of relative variability, Oikos, 88, 663-669.

[37] Sienkiewicz, P., \& Świeboda, H. (2006). Niebezpieczna przestrzeń cybernetyczna [A dangerous cyberspace], Transformacje, 1-4, 47-50.

[38] Skibińska, M. (2015). Czy pokolenia cyfrowe potrzebują edukacji informacyjnej? In: D. Siemieniecka (Ed.), Edukacja a nowe technologie w kulturze, informacji i edukacji [Education and new technologies in culture, information and communication] (pp. 49-67). Torun: Wydawnictwo Naukowe Uniwersytetu Mikołaja Kopernika.

[39] Slonje, R., \& Smith, P. K. (2008). Cyberbulling: another main type of bullying? Scandinavian Journal of Psychology, 49, 147-154. DOI: 10.1111/j.1467-9450.2007.00611.x

[40] Szewczyk, A. (2008). Problemy moralne w świecie informacji [Moral problems in the information world]. Warszawa: Wydawnictwo Diffin.

[41] Szymańska, J. (2012). Programy profilaktyczne. Podstawy profesjonalnej psychoprofilaktyki [Prevention programs. Fundamentals of professional psycho-prevention]. Warszawa: Ośrodek Roz- 
woju Edukacji. Retrieved 12 January, 2021 from http://www.bc.ore.edu.pl/Content/225/ programy_profilaktyczne_2012.pdf

[42] Tapscott, D. (2010). Cyfrowa dorostość. Jak pokolenie sieci zmienia nasz świat [Grown Up Digital How the Net Generation is Changing Your World]. Warszawa: Wydawnictwa Akademickie i Profesjonalne.

[43] Tkáčová, H., Pavlíková, M., Tvrdoň, M., \& Jenisová, Z. (2021). The Use of Media in the Field of Individual Responsibility for Sustainable Development in Schools, Sustainability, vol. 13(8), $1-21$.

[44] Warzecha, K. (2014). Internet w życiu współczesnego studenta: cele i intensywność korzystania a zagrożenie uzależnieniem [Internet in the life of the modern student, objectives and intensity using the risk of Internet addiction], Ekonomiczne Problemy Ustug, 113, 387-397.

[45] Warzecha, K. (2015). Aktywność wykonywana w sieci przez śląskich studentów niezagrożonych i zagrożonych uzależnieniem od Internetu - Analiza statystyczna [Activity exhibited on the Internet by the silesian students unthreatened Internet addiction and threatened Internet addiction - statistical analysis], Studia Ekonomiczne. Zeszyty Naukowe Uniwersytetu Ekonomicznego w Katowicach, 220, 99-116.

[46] Wojtkowiak, M., \& Szumilas-Praszek, W. (2013). Internet jako współczesne medium zagrożenia czy edukacji? Rola internetu w ponowoczesnym społeczeństwie [The Internet as a contemporary medium of threat or education? The role of the Internet in post-modern society], Spoteczeństwo i Rodzina, 4(37), 133-142.

[47] Xiao, B., \& Wong, Y. M. (2013). Cyber-bullying among University Students: An Empirical Investigation from Social Cognitive Perspective. Retreved 18 April, 2021 from https://www.researchgate.net/publication/263138446_Cyber-bullying_among_University_Students_An_Empirical_Investigation_from_Social_Cognitive_Perspective

[48] Ybarra, M. L., Mitchell, K. J., Finkelhor, D., \& Wolak, J. (2007). Internet Prevention Messages: Targeting the Right Online Behaviors, Archives of Pediatrics and Adolescent Medicine, 161(2), 138-145. DOI: 10.1001/archpedi.161.2.138D

[49] Zaleśkiewicz, T. (2006). Ryzyko jako konieczność i ryzyko jako przyjemność. Teoria i jej empiryczna weryfikacja. In: M. Goszczyńska, \& R. Studenski (Eds.), Psychologia zachowań ryzykownych. Koncepcje, badania, praktyka [The psychology of risk behavior. Concepts, research, practice] (pp. 19-45). Warszawa: Wydawnictwo Akademickie „Żak”.

[50] Zenebe, Y., Kunno, K., Mekonnen, M., Bewuket, A., Birkie, M., Necho, M., Seid, M., Tsegaw, M., \& Akele, B. (2021). Prevalence and associated factors of internet addiction among undergraduate university students in Ethiopia: a community university-based cross-sectional study, BMC Psychology 9(4). https:/ / doi.org/10.1186/s40359-020-00508-z

[51] Zucherman, M. (1994). Behavioral Expressions and Biosocial Bases of Sensation Seeking. New York: Cambridge University Press. 